\title{
Folate activity in human milk
}

\author{
BY B. V. RAMASASTRI \\ Nutrition Research Laboratories, Indian Council of \\ Medical Research, Tarnaka, Hyderabad, India \\ (Received 27 April 1965-Accepted I4 fune I965)
}

The available data on the folic acid content of human milk (Macy, r949; Collins, Harper, Schreiber \& Elvehjem, I95 I ; see also e.g. Macy \& Kelly, I96I) are based on determinations made at a time when the biochemical role of folic acid, and also the nature and properties of the biologically active cofactors of the vitamin, were imperfectly understood. It is now known that folic acid exists in a variety of forms, most of which are oxygen-labile. Use of ascorbic acid in the analytical procedure to prevent the loss of labile folate activity not only made possible the demonstration of the presence of a number of forms of folic acid in blood (Toennies, Usdin \& Phillips, 1956; Usdin, 1959), but also revealed the true levels of folate activity in it (Herbert, I96r; Waters \& Mollin, I96r; Grossowicz, Mandelbaum-Shavit, Davidoff \& Aronovitch, 1962).

As with blood, the possibility exists of the occurrence of various forms of folic acid in human milk. However, there are no recent published reports of the nature of folate activity in human milk. An investigation was therefore undertaken to reexamine this subject, and the results of this study showed that the true levels of folate activity in human milk are substantially higher than the values published earlier by others. The study also provided some indications of the nature of folate activity in human milk.

\section{EXPERIMENTAL.}

\section{Collection of milk samples}

Apparently normal and healthy lactating mothers at different stages of lactation were studied. Most of them belonged to the lower socio-economic section of the community and were not receiving any vitamin supplements. The samples of breast milk were always collected early in the forenoon by manual expression. The necessity of complete emptying of the breast did not arise because it was found in a study with four subjects that the folate activities were essentially the same in the fore, middle and end milk samples collected during the course of emptying of the breast by the infant. However, fore milks were usually collected for the analysis. The assays were begun as early as possible after the collection, the maximum period of storage being less than $20 \mathrm{~h}$ at $2^{\circ}-3^{\circ}$.

\section{Preparation of ascorbic acid solution}

Some batches of ascorbic acid (British Drug Houses Ltd, Bombay; Laboratory Reagent grade) were found to possess folic acid-like activity as judged by the heavy 
blanks in the assays, and treatment of the solutions with activated charcoal was found to remove this activity. Hence, as a routine, a $5 \%(\mathrm{w} / \mathrm{v})$ solution of ascorbic acid in water (I0-40 ml) was stirred with approximately $800 \mathrm{mg}$ of activated charcoal (E. Merck AG, Darmstadt) for $15 \mathrm{~min}$ and filtered. Titration with standard iodine solution in several experiments revealed a maximum loss of $17 \%$ of the ascorbic acid during treatment with charcoal, and hence the filtrate was considered to be an approximately $4 \%$ solution of ascorbic acid. An equal volume of $0.2 \mathrm{M}$-phosphate buffer, $\mathrm{pH} 7 \cdot 0$, was added to the filtrate, and the mixture adjusted to $\mathrm{pH} 6 \cdot 1$. An approximately $\mathrm{I} \%$ ascorbic acid solution was prepared by diluting the filtrate with water to four times the original volume.

\section{Microbiological assay procedures}

The procedure finally adopted for the estimation of folate activity in human milk was as follows. A known volume (usually $3 \mathrm{ml}$ ) was autoclaved for $\mathrm{I}_{5} \mathrm{~min}$ at $\mathrm{I}_{5} \mathrm{lb} / \mathrm{in}^{2}$ in the presence of $\mathrm{I} \mathrm{ml}$ of the approximately $\mathrm{I} \%$ solution of ascorbic acid prepared as above and sufficient $0.2 \mathrm{M}$-phosphate buffer, $\mathrm{pH} 7 \cdot 0$, to make the total volume to Io $\mathrm{ml}$. The cooled mixture was adjusted to $\mathrm{pH}_{4.5}$ and heated in a boiling water bath for $5 \mathrm{~min}$. This heat treatment helped to give clear filtrates. The mixture was then cooled to room temperature, diluted to a known volume and filtered. Finally, portions of the filtrate were adjusted to $\mathrm{pH} 6.8$ before dilution to known volumes for the assays.

Total folate activity was determined with Lactobacillus casei (ATCC 7469) in the medium described by Clegg, Kodicek \& Mistry (I952), but each assay tube contained, in addition, $\mathrm{r} \mathrm{ml}$ of a $0.25 \%$ solution of ascorbic acid (prepared by diluting fourfold the approximately I \% ascorbic acid solution described earlier). The total dilution of the samples for these assays was usually a hundredfold. The levels of standards used ranged from 0.05 to $0.4 \mathrm{ng}$ folic acid. ' $S$. faecalis activities' were determined by means of Streptococcus faecalis R (ATCC 8043) in the medium described by Herbert (1961), and as in assays with $L$. casei each assay tube contained I ml of the $0.25 \%$ solution of ascorbic acid. The total dilution of the samples for these measurements was six- to ten-fold, and the levels of the standards used varied from 0.5 to $4^{\circ} \mathrm{ong}$ folic acid.

A few samples of mature milk were analysed also for ' $P$. cerevisiae activity' with Pediococcus cerevisiae (ATCC 808I) in the assay medium described by Herbert (I96I) and in the presence of $\mathrm{I} \mathrm{ml}$ of $0.25 \%$ ascorbic acid solution in each assay tube. DL-calcium leucovorin (kindly supplied as a gift by Lederle Laboratories, New York) was used as the standard for these estimations, and the standard levels varied from $\mathrm{I} \cdot \mathrm{O}$ to $6 \cdot 0 \mathrm{ng}$ of the DL-form.

The growth responses were generally measured turbidimetrically after incubation of the inoculated tubes at $37^{\circ}$ for $3^{6-40} \mathrm{~h}$ for assays with $L$. casei, and for $18-20 \mathrm{~h}$ for the other assays. Under exceptional circumstances, and especially when the extracts were turbid, the growth responses were measured acidimetrically after incubation of the assay tubes for approximately $70 \mathrm{~h}$. Four levels were tested in duplicate with each sample and in most instances all the levels, or at least three of them, fell within the working range of the standard curve. No significant drifts were observed with the method used. 
Samples of milk were collected from four subjects at different stages of lactation and assayed with $L$. case $i$ with and without the use of ascorbic acid in the analysis. To find the magnitude of the possible differences in the folate levels in human milk as estimated with $L$. case $i$ and with $S$. faecalis, each of a few samples at different stages of lactation was analysed simultaneously with both the organisms.

\section{RESULTS}

Effect of incorporation of ascorbic acid in the medium on the total folate activity. The results (Table I) revealed significantly greater amounts of folate activity when ascorbic acid was used, especially in the transitional and mature milks. The use of higher levels of ascorbic acid in the various stages of the analytical procedure did not bring about any further recovery of folate activity.

Table I. Effect of incorporation of ascorbic acid in the medium on the total folate activity in human milk

$\begin{array}{cccc}\text { Subject } & \begin{array}{c}\text { Days } \\ \text { post } \\ \text { partum }\end{array} & \begin{array}{c}\text { With } \\ \text { ascorbic } \\ \text { acid }\end{array} & \begin{array}{c}\text { Without } \\ \text { ascorbic } \\ \text { acid }\end{array} \\ \text { A.B. } & 4 & 2 \cdot 9 & \mathbf{I} \cdot 6 \\ \text { V.S. } & 8 & 12 \cdot 1 & 1 \cdot 3 \\ \text { C. } & 18 & 11 \cdot 4 & 2 \cdot 5 \\ \text { T. } & 36 & \text { II.I } & 2 \cdot 1\end{array}$

Table 2. Folate activity ( $\mathrm{ng} / \mathrm{ml})$, measured with Lactobacillus casei or Streptococcus faecalis, in human milk at different stages of lactation

\begin{tabular}{|c|c|c|c|c|c|c|c|c|c|}
\hline & & Colostrum * & & Tra & nsitional mi & & & ature milk $\dagger$ & \\
\hline & $\begin{array}{l}\text { L. casei } \\
\text { activity } \\
\text { (a) }\end{array}$ & $\begin{array}{l}\text { S. faecalis } \\
\text { activity } \\
(b)\end{array}$ & $\begin{array}{c}b \text { as } \% \\
\text { of } a\end{array}$ & $\begin{array}{c}\text { L. casei } \\
\text { activity } \\
(c)\end{array}$ & $\begin{array}{l}S . \text { faecalis } \\
\text { activity } \\
(d)\end{array}$ & $\begin{array}{c}d \text { as } \% \\
\text { of } c\end{array}$ & $\begin{array}{l}L . \text { casei } \\
\text { activity } \\
\quad(e)\end{array}$ & $\begin{array}{l}\text { S. faecalis } \\
\text { activity } \\
(f)\end{array}$ & $\begin{array}{c}f \text { as } \% \\
\text { of } e\end{array}$ \\
\hline & $\begin{array}{l}5.4 \\
8.4\end{array}$ & $\begin{array}{l}6 \cdot 1 \\
6 \cdot 3\end{array}$ & $\mathrm{xr} 3$ & $\begin{array}{l}5 \cdot 6 \\
7 \cdot 0\end{array}$ & $\mathrm{I} \cdot 9$ & 34 & $11 \cdot 4$ & $\begin{array}{l}1.5 \\
. .8\end{array}$ & 13 \\
\hline & $\begin{array}{l}8.4 \\
3.4\end{array}$ & $\begin{array}{l}6 \cdot 3 \\
I \cdot 6\end{array}$ & $\begin{array}{l}75 \\
47\end{array}$ & $\begin{array}{l}7 \cdot 9 \\
4 \cdot 5\end{array}$ & $\begin{array}{l}4.4 \\
I \cdot 2\end{array}$ & $\begin{array}{l}56 \\
27\end{array}$ & $\begin{array}{l}150^{\circ} \\
13.0\end{array}$ & $\begin{array}{l}5.8 \\
6.0\end{array}$ & $\begin{array}{l}39 \\
43\end{array}$ \\
\hline & $5 \cdot 2$ & $I \cdot 9$ & 37 & $8 \cdot 4$ & $I \cdot 2$ & I4 & II. 4 & 5.5 & $\begin{array}{l}43 \\
48\end{array}$ \\
\hline & 3.0 & 0.8 & 27 & - & - & - & 一 & - & 一 \\
\hline Mean & $5 \cdot I$ & 3.4 & 60 & $6 \cdot 6$ & $2 \cdot 2$ & 33 & 13.0 & $4 \cdot 8$ & 37 \\
\hline
\end{tabular}

Comparison of $L$. casei and $S$. faecalis activities. The results of this study are presented in Table 2. The classification of the stages of lactation, although arbitrary, is the same as that used by Macy \& Kelly (196r).

The number of samples successfully analysed for the $S$. faecalis activity was small because of the low concentration of this activity in human milk, and also because of the low sensitivity of the method using this organism. The use of undiluted milk samples was found to result in significant 'drifts', and hence did not yield meaningful results. However, although the variations were large, the results indicated that the 
levels of $S$. faecalis-active folate material in human milk were small in comparison with the total folate levels. The mean $S$. faecalis activity formed $60 \%$ of the total folate activity in colostrum, and the proportion decreased to $33 \%$ and $37 \%$ in transitional and mature milks respectively. The ranges were for colostrum $27-$ I I $3 \%$, for transitional milk $1_{4}-56 \%$ and for mature milk $1_{3}-48 \%$.

P. cerevisiae activity. $P$. cerevisiae activity was not present in significant amounts in the few milk samples analysed. The use of undiluted milk caused drifts in these analyses also but indicated that the levels of the activity were of the order of less than I $\mathrm{ng} / \mathrm{ml}$.

Total folate activity. In view of the observation made above that $S$. facealis does not measure all the folate activity present in human milk, a number of samples were analysed by means of $L$. case $i$ in order to obtain values for the total folate concentration in normal human milk. The results obtained are presented in Table 3 . The range of values was wide in each stage of lactation presumably because of the random collection of samples from mothers with varied dietary regimens. However, the results clearly showed that, though the concentration of total folate was low in colostrum, it increased as lactation progressed.

Table 3. Total folate activity, measured with Lactobacillus casei, in human milk at different stages of lactation

\begin{tabular}{|c|c|c|c|c|}
\hline $\begin{array}{l}\text { Stage of } \\
\text { lactation }\end{array}$ & $\begin{array}{l}\text { No. of } \\
\text { samples }\end{array}$ & $\begin{array}{l}\text { Range } \\
\text { (ng/ml) }\end{array}$ & $\begin{array}{l}\text { Mean } \\
(\mathrm{ng} / \mathrm{ml})\end{array}$ & $\begin{array}{c}\text { SE } \\
\text { of mean }\end{array}$ \\
\hline Colostrum* & 14 & $2 \cdot 4-8 \cdot 4$ & 4.4 & $0^{\prime} 48$ \\
\hline Transitional & 9 & $4 \cdot 5-12 \cdot 1$ & $8 \cdot 4$ & 0.75 \\
\hline Mature $\uparrow$ & I9 & $7 \cdot 5-23 \cdot 7$ & I6.5 & $I \cdot I I$ \\
\hline
\end{tabular}

\section{DISCUSSION}

Collins et al. (1951), using $S$. faecalis for the assays, obtained a mean value of $0.71 \mathrm{ng}$ of folate activity/ml milk collected from five mothers at different stages of lactation. From a study of twenty-two subjects, Macy (1949) reported for mature milk a value of $2 \cdot 2 \mathrm{ng} / \mathrm{ml}$ with a range of $\mathrm{I} \cdot 4-3.6 \mathrm{ng} / \mathrm{ml}$. Although the method of assay could not be ascertained from the author's report, a publication by Toepfer, Zook, Orr \& Richardson (I95I) pointed out that the values were obtained with the use of either $S$. faecalis or $L$. case $i$ as the test organism. Assay values obtained with individual micro-organisms, however, were not given. The values for colostrum and transitional milks quoted in the literature (Macy \& Kelly, I96I) are 0.05 and $0.02 \mathrm{ng} / \mathrm{ml}$ respectively.

On the other hand, the results obtained in the study now presented with the use of improved assay media clearly show that, as with blood (Toennies, Frank \& Gallant, 1953; Herbert, 1961; Waters \& Mollin, 1961; Grossowicz et al. 1962), the amounts of $S$. faecalis-active folate material present in human milk are small and that assays with $L$. casei would give a better picture of the concentration of the total folate activity. 
The average total folate values of $4.4,8.4$ and $\mathrm{I} 6.5 \mathrm{ng} / \mathrm{ml}$ in colostrum, transitional and mature milks respectively obtained in my investigation are substantially higher than the corresponding values obtained by the earlier workers. The mean total folate value now obtained for mature milk is more than 4.5 times the highest value of $3.6 \mathrm{ng} / \mathrm{ml}$ reported by Macy (I949), who as mentioned above used $L$. casei also as the test organism. This indicates that the present high values are due not to a possible difference in the micro-organism used for the assay, but to incorporation of ascorbic acid in the procedure for the assays. When ascorbic acid was omitted in the assay, low folate levels, approaching those reported by Macy (1949), were found in the samples of milk. Herbert ( 1961 ) observed stimulation of the growth of $L$. case $i$ with ascorbic acid and phosphate buffer. In my study, however, it was found (results not given) that the growth responses of the micro-organisms to various levels of pure folic acid were the same in the presence and in the absence of the reducing agent. This finding, which is in line with that of Waters \& Mollin (I96I), rules out the possibility of stimulation of the growth of the test organisms as the cause for the increased values.

Karlin (1957), who used pancreatin from chicken liver to liberate folinic acid from the bound form, found that the folinic acid content of human milk decreased with the progress of lactation. My investigation, on the other hand, reveals an opposite trend. The total folate activity increases significantly as the lactation progresses to maturity. Although the details of the method used by Karlin could not be obtained, the values ranging between $\mathrm{I} .5$ and $8.5 \mathrm{ng} / \mathrm{ml}$ reported by him for mature milk are much lower than those obtained in my study, in which enzymes were not used to liberate the vitamin from the bound form.

Some speculation regarding the nature of folate activity in human milk is possible with my results. The significant loss of folate activity when ascorbic acid was omitted in the procedure suggests that the folates present in the milk are mostly in the reduced form. It is known that L. casei, $S$. faecalis and P. cerevisiae utilize reduced pteroylmonoglutamates (except methyltetrahydrofolate) equally well for their growth. However, the observation reported now that the level of $S$. faecalis activity is small compared to the $L$. case $i$ activity, together with the finding that $P$. cerevisiae activity is negligible, suggests that most of the folate in human milk is in a form utilized only by L. casei. It is known that pteroyltriglutamates and methyltetrahydrofolate are utilized as growth factors only by $L$. casei and not by $S$. faecalis or $P$. cerevisiae (cf. Usdin, 1959). Hence it seems possible that either or both of these compounds may constitute the major folate activity of human milk.

The $S$. faecalis activity constituted about two-thirds of the total activity in colostrum (Table 2). However, the absolute amounts of this activity remained more or less unchanged, or did not increase proportionately, in the more mature milks, and in many samples the amounts were well below those detectable by the procedure used. Hence it appears that the increase in the total folate activity with the progress of lactation may be mainly due to the increase in the levels of reduced pteroyltriglutamates, methyltetrahydrofolate or both. More work, however, with the use of folic acid conjugases is necessary to elucidate further the nature of folate activity in human milk. 


\section{SUMMARY}

r. Milk samples collected from apparently healthy mothers at different stages of lactation were analysed for folate activity.

2. With Lactobacillus casei as the test organism, considerably more folate activity was found to be present in human milk when ascorbic acid was used in the assay medium than when it was not.

3. The amount of folate material active for Streptococcus faecalis constituted only a small portion of the total folate activity present in transitional and mature milks. In colostrum, however, ' $S$. faecalis activity' formed about $60 \%$ of the total folate activity. No significant 'Pediococcus cerevisiae activity' was present in the few milk samples analysed for this activity.

4. The total folate activity was found to increase with the progress of lactation, and the mean values for colostrum, transitional and mature milks, $4.4,8.4$ and I $6.5 \mathrm{ng} / \mathrm{ml}$ respectively, were higher than those reported previously.

5. The results are consistent with the possibility that reduced pteroyltriglutamates, methyltetrahydrofolate, or both are the major folate compounds in the total folate activity of human milk.

I wish to express my thanks to Dr C. Gopalan, Director, Nutrition Research Laboratories, for his keen interest in this investigation, and to $\mathrm{Mr} \mathrm{E}$. P. Balakrishnan for his expert technical assistance. I am also grateful to the Clinical and Field Units of these Laboratories for the collection of the milk samples.

\section{REFERENCES}

Clegg, K. M., Kodicek, E. \& Mistry, S. P. (1952). Biochem. F. 50, 326.

Collins, R. A., Harper, A. E., Schreiber, M. \& Elvehjem, C. A. (I95I). F. Nutr. 43, 3 I3.

Grossowicz, N., Mandelbaum-Shavit, F., Davidoff, R. \& Aronovitch, J. (1962). Blood, $20,609$.

Herbert, V. (I96I). F. clin. Invest. 40,8I.

Karlin, R. (1957). C.r. Séanc. Soc. Biol. I51, 1211. (Quoted from Nutr. Abstr. Rev. (1958), 28, 1 247.)

Macy, I. G. (1949). Am. F. Dis. Child. 78, 589 .

Macy, I. G. \& Kelly, H. J. (196r). In Milk: the Mammary Gland and Its Secretion. Vol. 2, p. 265. [S. K. Kon and A. T. Cowie, editors.] New York and London: Academic Press Inc.

Toennies, G., Frank, H. G. \& Gallant, D. L. (1953). F. biol. Chem. 200, 23.

Toennies, G., Usdin, E. \& Phillips, P. M. (1956). F. biol. Chem. 221, 855.

Toepfer, E. W., Zook, E. G., Orr, M. L. \& Richardson, L. R. (r95r). Agric. Handb. U.S. Dep. Agric. no. 29.

Usdin, E. (1959). F. biol. Chem. 234, 2373.

Waters, A. H. \& Mollin, D. L. (1961). F. clin. Path. 14, 335. 